\title{
Regulations Matter: Epistemic Monopoly, Domination, Patents, and the Public Interest
}

\author{
Zahra Meghani $^{1}$
}

Received: 26 February 2021 / Accepted: 31 July 2021 / Published online: 16 September 2021

(c) The Author(s) 2021

\begin{abstract}
This paper argues that regulatory agencies have a responsibility to further the public interest when they determine the conditions under which new technological products may be commercialized. As a case study, this paper analyzes the US 9th Circuit Court's ruling on the efforts of the US Environmental Protection Agency (EPA) to regulate an herbicide meant for use with seed that are genetically modified to be tolerant of the chemical. Using that case, it is argued that when regulatory agencies evaluate new technological products, they have an obligation to draw on data, analyses, and evaluations from a variety of credible epistemic sources, and not rely solely or even primarily on the technology developer. Otherwise, they create conditions for their own domination and that of the polity by the technology developer. Moreover, in the interest of advancing the public interest, regulatory agencies must evaluate new technologies in a substantively and procedurally unbiased manner.
\end{abstract}

Keywords Regulatory agencies · Patents · Public interest · Epistemic monopoly · Domination · Epistemic responsibilities · Genetically engineered seed · Dicamba

\section{Introduction}

It seems uncontroversial that regulatory agencies (as agents of the democratic state) have a responsibility to further the public interest when they determine the conditions under which new technological products may be commercialized. However, it is not obvious what qualifies as the public interest and why regulatory agencies have a duty to foster it. Drawing on the work of political philosophers, this paper identifies some of the responsibilities of regulatory agencies. The argument is made that regulatory agencies should not create or condone epistemic monopolies that enable technology developers to dominate them or the polity. Otherwise, they violate their

Zahra Meghani

meghaniz@uri.edu

1 Philosophy Department, University of Rhode Island, Kingston, RI 02881, USA 
duty as state actors to advance the public interest when they regulate new technological products.

Regulatory agencies determine the conditions under which a variety of products, including technological products, may be commercialized. For instance, the range of entities and objects over which US regulatory agencies have purview is broad and varied. It includes milk, viruses, biologics, tobacco products, cosmetics, genetically modified $^{1}$ plants and animals, pharmaceuticals, and pesticides. Among other things, regulatory agencies are responsible for setting conditions for the safe and effective use of those organisms and objects as products.

As a case study, this paper analyzes the US 9th Circuit Court's ruling on the efforts of the US Environmental Protection Agency (EPA) to regulate dicamba, an herbicide. In 2016, the EPA issued a 2-year permit for the commercial use of three newly developed formulations of dicamba that were designed for use with seed that are genetically modified to be tolerant of the chemical. In 2018, the regulatory agency extended the commercial use permit for those new formulations of dicamba for another 2 years. It made that decision even though by then there were numerous credible public reports that the chemical drifted beyond the farm fields it was applied in, causing significant harm to off-site, non-target plants, bushes, and trees.

The EPA's 2018 decision to renew the permit for the newly developed versions of dicamba motivated three civil society organizations to file a complaint with the US 9th Circuit Court. In June 2020, the Court vacated the 2018 decision of the EPA to extend the commercial use permit for the three new formulations of dicamba. This paper analyzes the Court ruling because dicamba use has national and international significance. It is expected that the seed genetically modified to be tolerant of dicamba and the newly developed versions of dicamba meant for use with them are likely to achieve the same degree of market dominance in the USA as genetically modified seed that are modified to have the trait that makes them tolerant of glyphosate (an herbicide) and glyphosate itself ${ }^{2}$ (National Family Farm Coalition v. EPA, 2020, 48). Agrochemical companies that produce GE glyphosate-tolerant seed and glyphosate-based herbicides need a replacement for glyphosate. Weeds ${ }^{3}$ have become resistant to the chemical. ${ }^{4}$

To appreciate the market dominance of agrochemical companies' GE crops (and the herbicides and pesticides that are intended for use with them) and what that means for dicamba, it is useful to consider the data compiled by the Economic Research Service of the US Department of Agriculture (USDA). Currently, more than $90 \%$ of US corn, upland cotton, and soybeans are GE varieties (ERS, USDA

\footnotetext{
1 The terms "genetically modified" and "genetically engineered" are used interchangeably to denote organisms that have been modified by means of techniques of modern biotechnology.

2 Glyphosate has been the most widely applied pesticide on the planet (Benbrook, 2016). For a recent comprehensive overview of the scientific studies on the effect of glyphosate-based herbicides on the human endocrine system and its impact on other animal species, see Krimsky (2021).

3 The term "weeds" as used here refers to plants that are considered undesirable by farmers.

4 See Ravet et al. (2020), Loddo et al. (2020), and Gaines et al. (2020) reports for glyphosate resistance in North America, Europe, and South America, respectively.
} 
2020). The four other top cultivators of GE crops are Brazil, Argentina, Canada, and India. In 2019, along with the USA, they had $91 \%$ of the global GE crop area (approximately 190.4 million hectares) (ISAAA 2019). While only Spain and Portugal in the European Union cultivate GE crops, a number of other European countries import GE crops that they use primarily as feed. Of the more than 30 million metric tons (MT) of soybeans and soybean products imported by the EU, approximately $90-95 \%$ were genetically engineered, of the 10 to 20 million MT of imported maize products, an estimated 20-25\% were genetically modified, and of the 2.5 to 5 million MT of imported rapeseed products, approximately $25 \%$ were genetically engineered (ISAAA 2019). The point here is that if GE dicamba-tolerant seed and the three newly developed versions of dicamba replace glyphosate-tolerant seed and glyphosate-based herbicides in countries that cultivate GE crops, it will be internationally significant.

This paper analyzes the 9th Circuit Court's ruling with the aim of identifying some of the key duties of regulatory agencies that have purview over new technological products. It argues that when regulatory agencies choose to rely primarily or entirely on product sponsors for data, analyses, and evaluations, they in effect voluntarily subject themselves to an epistemic monopoly. In doing that, they create conditions for their own domination by those actors. Regulatory agencies should guard against being dominated because that may compromise their ability to foster the public interest (more on this later).

As agents of the democratic state charged with advancing the public interest, regulatory agencies also have a duty to not permit or participate in the domination of the polity. Not being dominated qualifies as a matter of public interest. Public interest is an interest that all persons have qua members of a democratic society (see Barry (1964), cited in O'Flynn (2010) and Boot (2020)). It is not specific to one's particular roles, be it as a parent, laborer, etc. (Barry, 1964, 14). The public interest is also not equivalent to the notion of the common good that communitarians invoke and which assumes a shared thick conception of the good life, nor is it to be understood as the aggregate of the particular interests that persons have in their specific roles. $^{5}$

Regulatory agencies have at least three epistemic duties to prevent powerful industries or corporate actors from dominating them or the polity. First, they must assess new technological products by drawing on data, analyses, and evaluations from a variety of credible sources and especially those who have been harmed or could be put at risk by the commercial use of those products. If regulatory agencies voluntarily substantively (or wholly) depend on product sponsors, they, in effect, chose to subject themselves to an epistemic monopoly. Their complete or significant epistemic dependency on the product sponsor may undermine their ability to accurately evaluate the safety and effectiveness of technological products. Second, the duty to accurately assess products also requires that regulatory agencies keep product developers at an arm's length. Third, regulatory agencies must evaluate

\footnotetext{
5 The conception of public interest as the aggregate of the particular interests of persons is attributed to Jeremy Bentham, and it is termed "compositionalism" (see Boot (2020) for a critique of it).
} 
products in a procedurally disinterested manner that advances the public interest. ${ }^{6}$ By analyzing these epistemic duties of regulatory agencies, this paper participates in the larger philosophical discussion about the responsibilities of regulatory bodies in democracies (see, for instance, Jasanoff, 2011; Meghani, 2014; Meghani, 2017; Meghani, 2019; Smuha, 2020; Floridi, 2021; Taylor, 2021).

The paper begins with a discussion of what it means for regulatory agencies to be autonomous. Then, the duty of the democratic state to further the public interest is analyzed and an account of public interest is extracted from it. Using that notion of public interest, the responsibilities of government agencies charged with regulating new technological products are explicated. After that, the EPA's regulation of dicamba is briefly described. The June 2020 ruling of the 9th Circuit Court against the agency is also delineated. Following that, the Court's ruling is analyzed. The final section of the paper identifies issues that remain unresolved.

\section{Autonomy of Regulatory Agencies}

Any account of the ethical duties of organizations should be cognizant of their capacity to function autonomously. An organization can be said to be autonomous if, among other things, it has the authority and resources to function in a manner that is in accordance with its mission and principles.

In the domain of ethics, individuals are construed as autonomous agents if they have the capacity to engage in self-determination (see, for instance, Immanuel Kant, Marilyn Friedman, and John Christman on that subject). ${ }^{7}$ Ethical theories conceptualize such individuals as autonomous even if they choose not to exercise that capacity. Autonomy is about having the ability to engage in self-determination. Ideally, they should exercise that capacity and choose to act ethically.

This paper contends that autonomy for regulatory agencies means something very different from autonomy for individuals. Unlike individuals, regulatory agencies must exercise their capacity to be self-determining, with the end of furthering the public interest. That is because as agents of democratic states regulatory agencies have a fundamental ethical and political duty to foster the public interest. However, their responsibility is limited to the domain over which they have authority (see, for instance, Shapiro (2012) and Barkow (2010)).

Regulatory agencies must function in a substantively and procedurally disinterested manner such that their rules, policies, guidances, decisions, practices, and actions further the public interest. The autonomy of regulatory agencies is tethered

\footnotetext{
6 This is not a comprehensive account of public interest, rather it is one sufficient for the purposes of this paper.

7 Immanuel Kant (1785 [1983]) conceptualizes autonomous persons as those who are capable of formulating and abiding by universal moral laws. In contrast, Marilyn Friedman (2003) has argued that an autonomous person is able to reflect on their deeper values and concerns and act in accordance with them even if they face some minimal degree of opposition by others. Their decision qualifies as autonomous if it is made by them on the basis of their values and concerns, without undue manipulation or coercion from others.
} 
to and shaped by their responsibility to foster the public interest. So regulatory agencies, unlike individuals, are obligated to act in an autonomous manner because they have a duty to advance the public interest. In other words, acting in an autonomous manner with respect to their responsibilities is a requirement for regulatory entities. It is not a matter of choice.

Regulatory agencies invariably face constraints, such as inadequate funding, as they attempt to advance the public interest, including attend to their mission. The ability of those organizations to do what they are supposed to do may also be curtailed by onerous and unrealistic requirements, especially if they are inadequately funded. For instance, the original and revised Toxic Substances Control Acts have placed on the US EPA enormous data collection and resource demands that has undermined the ability of the perpetually underfunded agency ${ }^{8}$ to protect public health and the environment (see Krimsky (2017) for a detailed analysis of this problem).

The autonomy of regulatory entities is shaped and constrained by their sociopolitical circumstance, including institutional context. In the USA, for instance, the institutional environment of federal regulatory agencies comprises of the legislative, executive, and judicial branches of the government (Croley, 2007; Magill, 2011). Theoretically speaking, the US Congress has virtually unlimited authority over regulatory agencies that is curtailed only by the Constitution (Magill, 2011). The President's authority over agencies has less scope than that of the legislative branch. The judiciary's oversight even more constrained: it is limited by statute (Magill, 2011).

To protect the autonomy of regulatory agencies and to prevent legislators from forcing them to serve corporate or industry interests rather than the public interest, limits on legislative control over regulatory bodies have been proposed (Croley, 2007, 74-75). Judicial review and presidential oversight may also protect regulatory agency autonomy "from legislators and interest groups who seek regulation that favors narrow interests," which would undermine the ability of regulatory bodies to further the public interest (Croley, 2007, 73).

The next section develops an account of public interest by drawing on the political philosophy and public administration scholarship about the responsibilities of the democratic state. It is then used to argue that regulatory agencies have an obligation to rigorously evaluate new technological products.

\section{The Public Interest and the Democratic State}

The ethical justification for the existence and authority of the democratic state is its commitment to advance the public interest. "Public interest" is at heart a moral notion, which is "principally concerned with the proper conduct of political life in democracies in general and the proper ways of making collectively binding political decisions in particular" (O’Flynn, 2010, 300). Barry (1964) has proposed that public

\footnotetext{
${ }^{8}$ See Harrison $(2011,101-103)$ on the EPA's inadequate budget.
} 
interest should be understood as the interest that all persons have qua members of a democratic society that is committed to the moral equality of all human beings.

Historically, liberal political philosophy has tended to equate the state's obligation to foster the public interest with respect for the political and civil rights of individuals. That notion of public interest has been subject to considerable criticism because of its limited conception of rights. Critics have argued that there is more to furthering the public interest than respect for individual civil and political rights. Rather the democratic state must also recognize and advance the economic rights of persons.

Some critics of the traditional liberal notion of the public interest have taken the position that the duty of the state to advance the public interest should not be understood in utilitarian terms. If the public interest is conceptualized in terms of actions (or inaction) by the state based on the preference of the majority (Ferdman \& Kohn, 2018), the minority is treated as if it matters less than the majority. That would violate the key tenet of democracy: everyone matters and matters equally and thus has the same rights ${ }^{9}$ (Nielsen, 1985).

The traditional liberal conception of the public interest has also been subject to the criticism that it fails to recognize that justice requires that the state should not create or permit conditions that result in the exploitation (or some other form of domination) of social groups (Schwartzman, 2006; Young, 1990; 2002). The public interest is harmed if any social group is not treated fairly. Fairness is to be understood as equitable treatment, rather than equal treatment. Providing the same amount and kinds of goods and services to all groups constitutes fair treatment only in the technical sense rather than in the substantive sense. If some groups have been or are exploited or marginalized, then merely providing them with the same goods and services as other groups will not be sufficient to remedy for the harms they have experienced or endure. More must be done to ensure that their life prospects are on par with those of groups that have not been and are not subject to those injustices. So, what is needed is equitable treatment rather than equal treatment. The democratic state must treat all groups equitably (Schwartzman, 2006; Young, 1990; 2002).

The democratic state and its agents (such as regulatory agencies) also should not create conditions for or permit their own domination. They have a duty to shield themselves from domination by third parties. Otherwise, their ability to act autonomously in the public interest is compromised. The democratic state exists to serve the polity and it is accountable to them.

Theoretically speaking, the power that the democratic state has over the polity does not qualify as domination because the power is legitimate and qualified (Skinner, 2002) ${ }^{10}$ In other words, the polity consented to being governed and it decided on the scope of the state's power. There are limits to the power of the democratic

\footnotetext{
9 For an account of this tension in J.S. Mill's work, see, for instance, Lyons (1994) and Brink (2010).

10 A state that governs without the consent of the public and without limits that are decided by it fails to recognize and respect the autonomy of the members of the polity (Skinner 2002). They are at its mercy and even the mere knowledge of that dependency places psychological constraints on persons such that their capacity to engage in self-determination is undermined (Skinner 2002, 257). Such a state lacks ethical and political legitimacy.
} 
state; its power is not categorical. For instance, it does not have the right to exploit (some or all of) the polity. It is accountable to those over whom it has authority and it is obligated to be transparent to them. The democratic state must recognize that the polity must have say over all matters that effect it. If any of those conditions are not met, the state fails to be ethically and politically legitimate, and it does not foster the public interest. The polity may remove it from office if it oversteps its boundaries or betrays the trust placed in it.

The democratic state's duty to advance the public interest includes an obligation to not harm it. Among other things, it means not creating or condoning conditions under which some organizations (say, corporations) acquire power over a segment (or the entirety) of the polity such that they are able to exploit it or dominate it in some other way (more on this below). Nor should democratic states or their agents, including regulatory agencies, create or condone states of affairs that allow other states or non-state actors to dominate them.

\section{The Public Interest and the Responsibilities of Regulatory Agencies with Respect to New Technological Products}

Regulatory agencies are part of and agents of the democratic state, so they share its duty to further the public interest. The particulars of their responsibility depend on their remit as regulatory bodies. For instance, to advance the public interest, an agency charged with protecting public health and the environment must correct environmental injustices (i.e., states of affairs when some social groups, relative to other groups, endure disproportionate risks or harms) (Liang et al., 2020). If the agency creates or allows conditions to exist that result in environmental injustice, it harms the public interest. As discussed earlier, the public interest is harmed if any social group is not treated fairly. For that reason, government agencies have a responsibility to treat all social groups equitably (Guy \& McCandless, 2012). So, state actors' duty to serve the public interest is not merely a question of respecting individual rights, rather it is also a matter of treating all social groups equitably (Svara \& Brunet, 2005, 254).

The ability of regulatory agencies to advance the public interest can be undermined by branches of the government. When members of the legislative branch are persuaded by business interests to adopt weak regulations or not regulate certain technologies or industries, regulatory agencies are not able to effectively (or at all) advance the public interest (Magill, 2011; Shapiro, 2012).

When a regulatory agency is required by law to not permit corporate actors to acquire monopolistic control, but it does not do so, then it fails to meet its ethical and legal obligation. It harms the public interest because, in effect, it enables the domination of (some segment or the entirety of) the polity by those corporations. ${ }^{11}$

\footnotetext{
11 For pragmatic arguments against market monopolies, see, for instance, IPES (2017) and Bratspies (2017). They make the case that monopolies make it very difficult for new companies to enter the market and undermine innovation efforts by other actors.
} 
When businesses become monopolies, they have disproportionate control over the marketplace such that members of the polity that need their products have to accept their terms. There are no viable alternatives for them. For instance, when a small group of corporations has proprietary rights over an agricultural biotechnology that farmers need to use, they can require them to accept their terms of sale whatever they may be. The 2017 report, Too Big to Feed, of the International Panel of Experts on Sustainable Food Systems (IPES) notes that

[t]oday, the proprietary seed industry is intimately linked to the world's largest agrochemical corporations. Syngenta (Switzerland), Bayer (Germany), BASF (Germany), DuPont (USA), Monsanto (USA), and Dow (USA), known as the "Big Six," currently control both $60 \%$ of the global seed market and $75 \%$ of the global pesticides market. (IPES-Food, 2017, 21)

In 2020, the "Big Six" consolidated into the "Big Four" with Bayer's purchase of Monsanto, and the merger of the agrochemical biotechnology sections of DuPont and Dow into Corteva. ${ }^{12}$ The 2017 IPES report argued that the mega-mergers between chemical-agriculture companies "has made farmers ever more reliant on a handful of suppliers and buyers, further squeezing their incomes and eroding their ability to choose what to grow, how to grow it, and for whom" (p.5).

As agents of the democratic state, the duty to nurture the public interest is the primary end-in-itself for regulatory agencies. So, they should not be complicit in the domination of (some or all of) the polity. Moreover, as part of their duty to foster the public interest, they should perform their work in a substantively and procedurally disinterested manner.

The substantive disinterestedness criterion requires that regulatory agencies keep proponents and developers of technologies at an arm's length. Citing Landis (1960), Latin (1991), and psychological studies, Shapiro (2012) notes that as industry representative meet with regulatory agency personnel on a much more frequent basis than environmental groups, it has a psychological effect on those government employees (117-118). They shift towards the position of the regulated parties "no matter how sincere and public-spirited officials are when appointed" (Shapiro, 2012, 118). (Also see Harrison (2011, 103-107), and more recently, Lerner (2021), on industry influence at the EPA).

The need for regulatory agencies to keep parties whose products they regulate at an arm's length is evident in the 2006 letter that the Local Presidents of (US) EPA Unions (representing thousands of scientists, risk managers, and related staff) sent to the EPA administrator. ${ }^{13}$ The letter expressed serious concern about the close relationship between the environmental agency personnel and the parties whose products they regulate, impairing the ability of the agency to attend to its mission of protecting human health and the environment:

\footnotetext{
12 For details and analyses of the Dow/DuPont, Bayer/Monsanto, and ChemChina/Syngenta mergers, see Bratspies (2017).

13 Cited in Harrison $(2011,105)$.
} 
Our colleagues in the (EPA's) Pesticide Program feel besieged by political pressure exerted by Agency officials perceived to be too closely aligned with the pesticide industry and former EPA officials now representing the pesticide and agricultural community; and by the USDA through their Office of Pest Management Policy. Equally alarming is the belief among managers in the Pesticide and Toxics Programs that regulatory decisions should only be made after reaching full consensus with the regulated pesticide and chemicals industry. (Welch et al., 2006)

If regulatory agencies do not or cannot keep product sponsors at an arm's length, the public interest may be harmed and regulatory agencies might not be able to meet their particular obligations (see, for instance, Krimsky and Gillam's (2018) analysis of Monsanto's influence on the EPA and its product's public health consequences). ${ }^{14}$ For a detailed account of pesticide companies' influence on EPA personnel, see Lerner 2021.

The substantive disinterestedness criterion also requires that regulatory agency not begin with the assumption that new technological products are valuable or useful. For instance, with respect to agricultural biotechnology products, regulatory agencies must take an agnostic attitude towards the "goodness" of agricultural biotechnologies in general and particular agricultural biotechnologies. They must not start with the belief that agricultural biotechnologies are good, regardless of their particulars or context of use.

In contrast to the substantive disinterestedness standard, the procedural disinterestedness criterion requires that regulatory agencies create and abide by protocols that enable them to rigorously evaluate new products. When evaluating two competing products, a regulatory agency must conduct procedurally unbiased assessments that foster the public interest. Not only should both products be subject to the equivalent battery of safety tests, but the tests must have as their larger aim the public interest. To perform procedurally unbiased evaluations, regulatory agencies should also draw on a variety of credible resources for data, analyses, and evaluations of the new technological products. They should not solely or primarily depend on the technology developer.

There are a variety of epistemic (i.e., knowledge seeking and knowledge creating) procedures that regulatory agencies are able to use to conduct unbiased and rigorous risk assessments, with the end of making informed regulatory decisions about products. For instance, the US Food and Drug Administration and the EPA routinely use advisory committees to that end (Weimer, 2006, 571).

Legal scholar and US public administration expert Croley has detailed the procedures that US regulatory agencies may and do use to get data, information, analyses, and evaluations about products:

\footnotetext{
14 Also see, Bird et al.'s (2021) review of the talc industry's influence on the FDA; it is a detailed case study that serves as an argument for regulatory agencies keeping product sponsors and industry at an arm's length.
} 
[A]gencies have very robust processes for gathering and evaluating information: They employ policy analysts, including economists, accountants, and scientists. They rely on peer review. They also solicit advice from experts and other consultants. They convene advisory groups. They publicize their findings and disclose other studies on which their proposals rely. In addition to all of that, agencies also often quantify the costs and benefits of proposed regulatory decisions, and invite interested parties to comment on the same. In short, regulatory agencies are not dependent upon regulated parties for either information or expertise. The idea that regulated interests can fool agencies fails to consider the considerable infrastructure agencies have developed to generate and process information $(2007,236-237)$.

So, these are known epistemic standards and norms for regulatory agencies that have purview over technological products. Regulatory agencies' autonomy (i.e., their ability to advance the public interest) is partially a function of their use of those procedures and resources.

If a regulatory agency's protocol obligates it to draw solely (or primarily) on the data, analyses, or evaluations provided by the sponsor of the product or those who have a vested interest in it, then its decisions may be biased in favor of those interests (Croley, 2007, 75). For instance, when regulatory agencies wholly (or disproportionately) rely on the developers of an agricultural biotechnology for evaluating the safety of and risks from their product, they compromise their ability to act for the public interest. Data, analyses, and evaluations from those who have been harmed or will be put at substantial risk from the product could help regulatory agencies appraise the safety of and risks from the biotechnology more rigorously (including accurately).

The importance of regulatory agencies not depending solely or mainly on product sponsors or industry becomes clear when it is taken into account that there are cases of corporations and industries skewing studies and study results about their products, as well as not allowing negative results about their products to be published (see, for instance, Lexchin (2012) and Bohme et al. (2005) for a general discussion and examples of this ethical and epistemic problem; see Tran et al. (2019) for a detailed case study). Developers of new technologies may also "frame" their products in peer-reviewed publications as the solution or a necessary part of any solution to a particular problem, even though that may be at odds with analyses developed by other scientific experts who are differently situated (see, for instance, Meghani, 2020). Fernández Pinto and Hicks (2019) note that some product sponsors and industries invoke unrealistic epistemic standards to discount research that is critical of their products and undermine efforts to regulate them effectively (see, for instance, McGarity, 2003; Oreskes and Conway, 2010; Proctor, 2012; Trasande et al., 2016). To get a grasp on the (public interest) value of regulatory agencies conducting rigorous assessments of risks from new technological products, it is illuminating to examine the 9th Circuit Court's ruling in National Family Farm Coalition v. US EPA. In June 2020, the Court found that the EPA did not attend to its legal responsibilities (which included epistemic duties) when it made the decision in October 2018 to extend the permit for the commercial use of lower volatility 
formulations of dicamba, an herbicide meant for use with dicamba-tolerant GE seed. That affected the EPA's ability to advance the public interest.

\section{The Case of Dicamba}

\subsection{The EPA's Regulation of Dicamba}

Starting in the late 1990s, farmers in the USA increasingly used the herbicide glyphosate (the key ingredient in Monsanto's Roundup brand name products) on their fields to kill weeds (National Family Farm Coalition v. EPA, 2020). The herbicide was meant for use with Monsanto's genetically engineered (GE) cotton seed and GE soybean seed. The GE seed were modified to be tolerant of glyphosate and they had been de-regulated in the late 1990s by Animal and Plant Health Inspection Service (APHIS), a regulatory agency within the US Department of Agriculture (USDA) that has oversight over GE plants. The herbicide did not affect the GE plants, but harmed plants that were not tolerant of it.

However, by the early 2000s, plants considered weeds by farmers had become tolerant of glyphosate. Presumably as a replacement for glyphosate, Monsanto chose dicamba, a different herbicide and began developing corn and soy that would be tolerant of it. At that time, dicamba had been available for decades in the US marketplace. However, it was not widely used on farms because of its volatility. It could drift as it was being sprayed if there was wind, it could also drift if it was applied in the midst of temperature inversion, and after application it could volatilize or change into vapor in hot weather and drift to areas where it was not supposed to be. When applied in farm fields, it would drift off-site and cause harm to non-target plants, bushes, and trees. It was known to have damaged fruit trees, tomato bushes, grapes, beans, peas, potatoes, flowers, and ornamental plants (Schroeder, 2020).

Monsanto developed and patented GE soybean and GE cotton that were modified to be tolerant of dicamba (henceforth, referred to as GE (DT) crops). Monsanto (now Bayer), Corteva (formerly DuPont), and BASF also developed formulations of dicamba with reduced volatility, specifically, XtendiMax (Bayer), Engenia (BASF), and FeXapan (Corteva) (National Family Farm Coalition v. EPA, 2020, 8). Those three new formulations of dicamba were meant for use with Monsanto's GE (DT) soybean and GE (DT) cotton plants.

In 2015, the USDA's APHIS approved the use of Monsanto's GE (DT) seed. Farmers began using them with the formulation of dicamba that was already on the market (National Family Farm Coalition v. EPA, 2020, 9).

The EPA has jurisdiction over pesticides and herbicides, including those intended for use with GE seed and crops. For commercial use, pesticides and herbicides must be registered with the agency. In 2016, pursuant to the Federal Insecticide, Fungicide, and Rodenticide Act, 7 U.S.C. $\S 136$ et seq., the EPA granted conditional, 2-year registration to the three lower volatility formulations of dicamba sponsored by Monsanto (now Bayer), Corteva (formerly DuPont), and 
BASF. The chemicals were meant for over the top (OTT) use on GE (DT) crops (National Family Farm Coalition v. EPA, 2020, 8-9).

The EPA justified its 2016 decision to register the dicamba formulations with lower volatility for commercial use on the grounds that if those chemicals were used according to the instructions on their label, the benefits would outweigh "any remaining minimal risks (from their use), if they exist at all" (EPA quote in National Family Farm Coalition v. EPA, 2020, 10). The EPA also stated that the restrictions on dicamba's use were "expected to eliminate any offsite exposures" to the herbicide (EPA quote in National Family Farm Coalition v. EPA, 2020, 12). In other words, the agency seemed to assert that the three new lower volatility formulations of dicamba if used in accordance with the instructions on the label of their containers would guarantee that the chemical would not drift to areas where it was not supposed to be and cause off-target damage. The EPA approved the 2016 (initial) commercial registration of Monsanto's lower volatility dicamba formulation drawing solely on the studies submitted by the company because "Monsanto did not at that time make its herbicide available for independent studies" (National Family Farm Coalition v. EPA, 2020, 28).

\subsubsection{The 2017 Growing Season}

In 2017, state-level agricultural agencies, various agricultural organizations, and the EPA itself received numerous complaints of dicamba drift damage to crops, plants, bushes, and trees that were not engineered to be dicamba tolerant (National Family Farm Coalition v. EPA 2020). Newspaper articles detailed complaints of dicamba drift from the neighbors of the farmers who planted GE (DT) crops in their fields and used dicamba on them. The drift meant that the principle of co-existence of different primary production systems was violated. Hubbard and Hassanein (2013) write that the principle refers to a "condition where different primary production systems can exist concurrently or in the vicinity of each other, and can be managed in such a way that they affect each other as little as possible."

In response to "what the EPA characterized as high number of crop damage" during the 2017 growing season, Monsanto offered to make changes to the label of its formulation of dicamba (National Family Farm Coalition v. EPA, 2020, 11). After consulting with state-level agencies and the USDA about the revisions to the label, the EPA approved additional restrictions on the use of the chemical. ${ }^{15}$ The key new (additional) conditions that farmers using the lower volatility versions of dicamba had to abide by were as follows (National Family Farm Coalition v. EPA, 2020, 13):

\footnotetext{
15 The agency introduced the additional restrictions without going through a formal registration amendment process (National Family Farm Coalition v. EPA 2020, 11) or preparing a new risk assessment even though new evidence had emerged about the volatility of the herbicide's new formulation (National Family Farm Coalition v. EPA, 2020, 13-14).
} 
i. It was not to be applied if the wind speed was greater than 10 miles per hour (previously, it could be applied in wind speeds up to 15 miles per hour).

ii. It could only be applied between sunrise and sunset (previously, it could be applied at any time except during temperature inversion).

iii. It was to be labeled as "restricted use pesticides" and could only be applied by certified (dicamba) applicators or persons directly supervised by them.

\subsubsection{The 2018 Growing Season}

In 2018, in the USA, 56 million acres out of a total of 103 million acres of soybean and cotton were planted with Monsanto's GE (DT) seed (National Family Farm Coalition v. EPA, 2020, 14). It was an increase of 29 million acres from the previous year devoted to the dicamba-tolerant GE seed. By July 15, 2018, university-affiliated scientists who study weeds calculated that approximately 1.1 million acres of soybean (that were not dicamba tolerant) in 18 states had suffered damage from the herbicide (National Family Farm Coalition v. EPA, 2020, 14). In contrast, by July 2017, university scientists had estimated 2.5 million acres of non-GE (DT) soybean were damaged by the herbicide (it is not known data from how many states was included in the figure). The lower amount of damage in 2018 was attributable to the EPA's additional restrictions on the use of the herbicide as well as restrictions placed on the use of dicamba by individual states (see Table 1 for examples of statelevel (additional) restrictions on use of OTT dicamba (National Family Farm Coalition v. EPA, 2020, 14-15)). ${ }^{16}$

Table 1 Examples of state-level (additional) restrictions on use of OTT dicamba

\begin{tabular}{llll}
\hline State & $\begin{array}{l}\text { Number of complaints } \\
\text { in } 2017\end{array}$ & $\begin{array}{l}\text { Number of com- } \\
\text { plaints in } 2018\end{array}$ & $\begin{array}{l}\text { State-level restrictions (in addition to } \\
\text { EPA's restrictions) on the use of OTT } \\
\text { dicamba herbicide during of OTT } \\
\text { dicamba herbicide during the 2018 } \\
\text { growing season }\end{array}$ \\
\hline Arkansas & 986 & 200 & $\begin{array}{l}\text { OTT application of dicamba was pro- } \\
\text { hibited between April 16th-Oct 31st } \\
\text { (i.e., the entire growing season) }\end{array}$ \\
& 29 & $\begin{array}{l}\text { i. } \begin{array}{l}\text { Before June 20th, OTT application of } \\
\text { dicamba was forbidden on days when } \\
\text { the temperature was greater than } 85{ }^{\circ} \mathrm{F} \\
\text { (i.e., 29.44 }{ }^{\circ} \mathrm{C} \text { ) }\end{array} \\
\text { After June 20th, OTT application of } \\
\text { iicamba was forbidden }\end{array}$ \\
\hline
\end{tabular}

\footnotetext{
${ }^{16}$ For a more detailed state by state response to dicamba drift damage, see National Family Farm Coalition v. EPA, 2020, 14-16.
} 
Unlike Arkansas and Minnesota, during the 2018 growing season, Illinois relied solely on the EPA's restrictions (on the label of containers of dicamba). In 2017, in Illinois, there were 245 complaints of dicamba drift harm (National Family Farm Coalition v. EPA, 2020, 16). In 2018, there were 330 complaints of drift damage to crops from dicamba for that state.

\subsection{The EPA's 2018 Decision to Extend the Commercial Use Permit for the Newly Developed Lower Volatility Formulations of Dicamba}

While the damage from dicamba drift was well publicized and extensively documented, in October 2018, the EPA decided to extend its 2016 registration of the three lower volatility formulations of dicamba for another 2 years (i.e., 2019-2020). The agency justified its decision on the grounds that, first, the OTT (lower volatility formulations of) dicamba provided farmers with an additional means for controlling broadleaf weeds during the growing seasons, especially for significant weeds (such as Palmer amaranth) that were herbicide tolerant. Second, the lower volatility formulations of dicamba were an additional tool for delaying the development of herbicide resistance in weeds if used during the length of the growing season (National Family Farm Coalition v. EPA, 2020, 16).

The EPA's Oct 2018 decision to extend the commercial use permit of the three lower volatility formulations of dicamba referenced a slideshow from Monsanto's 2018 quarter financial results (National Family Farm Coalition v. EPA, 2020, 18). The agency stated that the company anticipated that 40 million acres of DT (GE) soybean would be planted on US farms. From that, the EPA estimated that $55 \%$ of non-DT (GE) soy crops could "potentially be damaged by very low levels of offtarget dicamba" (EPA, quoted in National Family Farm Coalition v. EPA, 2020, 18). The agency also acknowledged damage from dicamba drift to other plants, included "about 250 weeds - annual and perennial broadleaf plants and trees_-...some of which are desirable in non-crop settings" (EPA, quoted in National Family Farm Coalition v. EPA, 2020, 18). However, the EPA did not quantify the damage.

In extending the (initial) commercial use permit for the three lower formulation versions of dicamba to the 2019-2020 period, the EPA introduced additional restrictions on their use. The 'label' for the lower volatility versions of dicamba was forty pages long (National Family Farm Coalition v. EPA, 2020, 43). It included the following stipulations about the chemical's use on GE (DT) crops (National Family Farm Coalition v. EPA 2020, 19):

i. It could only be applied within one hour of sunrise or two hours prior to sunset (not at any time during the day).

ii. Only two OTT dicamba applications were permissible for each crop of DT (GE) soybeans (the second application had to occur within 45 days of planting).

iii. Only two OTT dicamba applications were allowable for each DT (GE) cotton crop, with the second application within 60 days of planting.

iv. To protect certain plant species, a 57-ft buffer zone around the entire DT (GE) crop field was required in specific counties. 
The crucial question at that point in time was whether farmers could reasonably be expected to safely and legally use the chemical under the very restrictive conditions specified on the label of containers of the lower volatility formulations of the herbicide. The EPA's stipulation of those conditions, arguably, shifted the responsibility of the safe and legal use of the herbicide from the manufacturer on to the shoulders of farmers who planted the GE (DT) seed (more on this below).

\subsection{The 9th Circuit Court's National Family Farm Coalition v. US EPA Ruling}

Three civil society organizations voiced objection to the October 2018 EPA decision to extend the commercial use permit of the three lower-volatility formulations of dicamba. They sought judicial intervention on behalf of constituencies that had been harmed by the 2016 decision of the EPA to permit the commercial use of the newly developed lower volatility versions of dicamba. The National Family Farm Coalition, the Center for Food Safety, the Center for Biological Diversity, and the Pesticide Action Network North America filed a petition with the 9th Circuit Court asking for a judicial review of the agency's decision. The EPA was the respondent, and Monsanto was the respondent-intervenor.

On June 3, 2020, the 9th Circuit Court ruled against the EPA. It vacated the agency's 2018 decision that permitted the three-lower volatility dicamba formulations to remain on the market. The ruling noted that the agency is required by law to take into account the social cost of the use of the product under review, but the EPA did not do so in its October 2018 dicamba decision. The Court concluded that the agency's October 2018 decision to extend the registration of the lower volatility formulations of dicamba did not factor in the experience of farmers whose crops were damaged because their neighbors planted GE (DT) seed and used dicamba on them during the 2017 and 2018 growing seasons (National Family Farm Coalition v. EPA, 2020, 48-51). Dicamba drift created significant rips in "the social fabric of farming communities" because it damaged plants, crops, and trees that were not tolerant of it (National Family Farm Coalition v. EPA, 2020, 5).

According to the ruling, the EPA's 2016 initial commercial use registration of the lower volatility dicamba versions and then the October 2018 extension of that permit (for another 2 years) created substantial risk of anti-competitive economic impact in the soybean and cotton industries (National Family Farm Coalition v. EPA, 2020, 48-51). If a farmer used GE (DT) cotton or soybean, and thus, dicamba as herbicide, her neighbors who were farmers felt pressured to use the GE seeds modified to be tolerant of that chemical. Otherwise, their crops would be damaged if the herbicide drifted on to their fields when their neighbor used it on her fields. By not acknowledging that the use of the herbicide by farmers made their neighbors who were farmers feel that they had to switch to GE (DT) crops otherwise they would suffer very significant losses, the Court noted that the EPA was ignoring that a market monopoly of the herbicide and the GE (DT) seed was in the process of being established (National Family Farm Coalition v. EPA, 2020, 49). According to the 9th Circuit Court, the EPA was aware that Monsanto's glyphosate-resistant trait, and glyphosate herbicide use "had achieved a near-monopoly" and that the patented GE (DT) seed 
and the three lower volatility formulations of dicamba were likely to have the "same degree of dominance" (National Family Farm Coalition v. EPA, 2020, 48). Between 2017 and 2018, Monsanto's DT (GE) soybeans increased from 25\% of US soybean to 50\% (National Family Farm Coalition v. EPA, 2020, 48-49). The Court noted that the EPA is legally required to consider the possible anti-competitive impact of the products it reviews, but it did not attend to that responsibility in 2018 when it reviewed the application to extend the permit for dicamba's commercial use. So, this was the second way in which the agency did not fulfil its epistemic duties.

The Court also criticized the EPA for not exercising its epistemic agency in a different regard. Specifically, in its October 2018 decision to extend the permit for the lower volatility dicamba, the EPA characterized the damage from the herbicide as "potential" and "alleged" even though "record evidence showed that dicamba had caused substantial and undisputed damage" (National Family Farm Coalition v. EPA, 2020, 5, 39). The Court noted that the agency failed "to quantify or estimate the amount of damage caused by OTT application of dicamba herbicides, or even to admit that there was any damage at all" (National Family Farm Coalition v. EPA, 2020, 5, 39). The Court concluded that by late 2018 the EPA had both quantitative and qualitative data of dicamba drift damage. For instance, the Acting Chief of the herbicide branch of the EPA's Office of Pesticide Programs stated at a meeting in Washington, D.C. in September 2017 with state regulatory officials that "the agency was 'very concerned with what has occurred' with the OTT (over-the-top) use of dicamba" (National Family Farm Coalition v. EPA, 2020, 12). At a September 2018 presentation, he "confirmed that '[m]ore than 3.6 million acres' of soybeans had been damaged by dicamba during the 2017 season" (National Family Farm Coalition v. EPA, 2020, 12). The Court ruling noted that Acting Chief of the herbicide branch of the EPA's Office of Pesticide Programs stated that that figure was probably an underestimate because state-level departments of agriculture did not receive all crop damage reports (National Family Farm Coalition v. EPA, 2020, 12).

As the damage from dicamba drift was known to key EPA senior personnel and it was public knowledge, the Court stated that the EPA could have "quantified dicamba damage, even if it could not have calculated with precision the reduction in yield caused by the damage" (National Family Farm Coalition v. EPA, 2020, 39). It should have factored that information in its 2018 decision about the permit extension of the herbicide, but it chose not to do so.

The EPA's strategy of stipulating increasingly specific and restrictive conditions for legal use of the lower volatility versions of dicamba (i.e., 40 pages of regulation by labeling) did not advance the public interest. It shifted the responsibility of safe and legal use of the chemical on to the shoulders of individual farmers, while allowing the product sponsors to keep selling and growing its market share of the herbicide and the GE (DT) seed. It also meant that risks and harms continued to be imposed on the neighbors and communities of farmers who used the herbicide because of the possibility of damage from dicamba drift to plants, bushes, and trees that were not tolerant of the chemical. Those risks and harms were foisted on those neighbors and communities: they did not consent to undertake them. The case could be made that the EPA's decision to renew the permit for the three newly developed 
formulations of dicamba created conditions for their domination. Arguably, the agency's 'regulation' of dicamba drift can be seen as part of a pattern of pesticide drift regulation in general, including pesticides that cause illness in humans (for a detailed analysis of the history of the problem of pesticide drift in the USA, see Harrison (2011)). Some constituencies are compelled to bear risks and harms; they have little or no say in the matter.

\section{An Analysis of the 9th Circuit Court's Ruling}

The Court's ruling is a rebuke to the EPA for not attending to its ethical and legal duties, which included the epistemic obligation to rigorously (including accurately) evaluate the safety of and risks from products. As noted in the ruling, the EPA should have taken into account the anti-competitive effect of the use of the dicamba formulations. By not acknowledging that the use of the herbicide by farmers made their neighbors who were farmers feel that they had to switch to GE (DT) crops otherwise they would suffer very significant losses, the EPA was ignoring that a market monopoly of the product (i.e., dicamba) and the GE (DT) seed was in the process of being established. As discussed earlier, when a regulatory agency is legally obligated to take into account in its risk evaluations and decisions the possible anti-competitive impact of products, but chooses not to do so, it violates its duty to further the public interest. Arguably, it becomes complicit in monopolistic control of the marketplace by corporate actors, to the detriment of the public interest.

Another crucial problem noted by the 9th Circuit Court, but whose root cause was not addressed by it, was the EPA's exclusive reliance on the product sponsor for data, analysis, and evaluation of the new lower volatility formulation of dicamba. According to the 9th Circuit Court, in 2016, the agency relied solely on Monsanto's safety and risk data for its (initial) risk assessment and registration decision; the company had refused to provide its product to other parties (presumably, scientists and organizations concerned about the chemical) for independent studies (National Family Farm Coalition v. EPA, 2020, 28).

This is not an isolated instance of over (or complete) reliance of the agency on product sponsor. Regarding the EPA's history of extensive epistemic reliance on industry, Harrison (2011) writes, "Congress and the EPA's own scientists have criticized the agency consistently since at least the 1960s for not verifying the validity of those industry data, and industry has been found to have withheld data showing that particular chemicals under review (and in use) pose serious health hazards" (99).

One possible way to prevent this problem would be for the EPA to issue guidance documents that clarify to the agrochemical and agribiotechnology industry that before they apply for commercial permits for their products, they should make their products available for independent studies to third parties that are not affiliated with them or dependent on them (in any way). While guidance documents, including those issued by the EPA, are usually not legally binding, they carry considerable weight because regulatory agencies routinely use them to provide industry with 
their current thinking on specific issues (EPA (undated)). Some guidance documents describe the agency's interpretation of policy, including the design, production, labeling, promotion, manufacturing, and testing of regulated products. Guidance documents may also detail inspection and enforcement policies (FDA, 2016). ${ }^{17}$

By issuing a guidance to the agrochemical and agribiotechnology industry that they should make their products available for study to third-party university scientists and civil society organization scientists who are not affiliated or dependent on them in any way, the EPA would only be ensuring that it could abide by the epistemic norms for regulatory agencies. After all, it is a well-established and longstanding norm and practice for US regulatory agencies to draw on a variety sources for data, analyses, and evaluations of the products under review (Croley, 2007, 236-237). The ability of environmental agencies to make informed regulatory decisions that further the public interest is enhanced when they have access to data, analyses, and evaluations of products and their risks from a variety of credible sources, and not just the product sponsors.

The ruling also left untouched another serious epistemic and ethical problem with the regulation of new technological products. Regulatory agencies have the discretion to decide what weight they will give in their decisions to the data, analyses, or evaluations developed by constituencies other than the product sponsor. Among other things, that means they have the latitude to discount the epistemic contributions of those who are independent third parties or those who have been harmed (or will be put at risk) by the commercial use of the technological product. Those contributions have a particular epistemic value because they have the potential to be crucial correctives to the data, analyses, and evaluations provided to regulatory agencies by product sponsors. However, under the current regulatory system, the EPA (as in the case of the lower volatility formulations of dicamba) has the discretion to determine how much weight it will give to those contributions in its decisions about new technologies.

According to the 9th Circuit Court, the decision of the EPA to not accurately estimate the dicamba damage in the face of record evidence, in effect, amounted to a refusal of the EPA to attend to its responsibility as a regulatory agency charged with accurately evaluating harms and risks from new technological products. If there is substantial evidence of harm or risk from a product, regulatory agencies are obligated to at least estimate the damage and factor that into their decision-making about whether to permit the product to remain on the market. If a regulatory agency does not act on such information, it violates its duty to further the public interest. (Not harming public interest is a necessary, but not sufficient, condition of advancing the public interest.) The Court considered that the EPA should have acted on its obligation to furthering the public interest by making an informed decision about extending the permit for the new technological product. Specifically, it should have taken into consideration relevant data, analyses, and evaluation that were widely available to it from credible sources about the harms and risks from dicamba use. The EPA should have been particularly attentive and responsive to constituencies who had been harmed by or were at significant risk from those products. That would have enabled it to accurately and more rigorously evaluate the lower volatility

${ }^{17}$ For a history of the changes in the legal status of guidance documents, see Noah (1997). 
formulations of the herbicide, and then make an informed decision about whether to extend their registration for another 2 years.

The 9th Circuit Court's June 2020 ruling was a stern rebuke to the EPA. However, its impact on the agency is unclear. Three months after the ruling, in October 2020, the EPA approved the registration of two new dicamba products and extended the registration of other dicamba formulations until 2025. The registration included new control measures intended to ensure their effective use while "protecting the environment, including non-target plants, animals, and other crops not tolerant to dicamba" (EPA, 2020). Key agency personnel justified their decision on the grounds that it would give farmers the certainty they needed for the next (i.e., 2021) growing season, and the agency made the decision after "reviewing substantial amounts of new information, conducting scientific assessments based on the best available science, and carefully considering input from stakeholders" (EPA, 2020). The 2021 growing season will be telling.

Next, three unresolved issues are delineated.

\section{Unresolved Issues}

The 9th Circuit Court's decision (to vacate the lower volatility formulations of dicamba commercial use permit's extension) brings to light three key underlying unresolved problems with the regulation of new technologies. First, judicial oversight of regulatory agencies is a chancy matter. Those who have been harmed or might be put at significant risks from a technological product that has been approved or de-regulated must have (legal) standing for the courts to take up their request for review of an agency's decision. Stewart has argued that by the mid-1970s, US administration law underwent key doctrinal changes. ${ }^{18}$ Statutes widened the classes of interests that had legal standing in formal agency processes. The federal courts were increasingly willing to scrutinize agency actions. A broader range of interests were recognized by the courts as having standing under the Constitution to request administrative hearings. The federal courts recognized that a larger class of interests had legal standing to request judicial review of decisions made by regulatory agencies. $^{19}$

Those doctrinal changes are reassuring, but only to a degree. Depending on the political climate of the country, statutes could be enacted to narrow the class of interests that have legal standing to initiate judicial review of regulatory agency decisions. If that occurs, it could mean that if regulatory agencies did not protect themselves or the polity from domination by the developers of new technological products, the affected groups may not have access to the courts as a way of holding them responsible. For instance, if a regulatory agency chose not to exercise its epistemic agency (by drawing on data, analyses, and evaluations about a new technological product from a variety of sources), but instead decided to rely solely on the

18 This analysis is drawn from Weimar's analysis (2005) of Stewart (1975).

${ }^{19}$ Also, see Jasanoff (2011) about the political circumstances under which this change occurred. 
technology developer, the affected groups and civil society organizations might not be able to hold them accountable. So, this is an intractable and significant problem with the regulation of new technological products in societies where power relations between groups are inequitable.

There is another serious problem that the dicamba case serves to illuminate. The ability of a regulatory agency to act autonomously so as to advance the public interest may be constrained by the actions of other regulatory bodies. For instance, while the 9th Circuit Court's decision applied to the EPA, the ruling can also be read as an indirect rebuke to the USDA, which, in 2015, de-regulated the use of GE (DT) crops, even though at that time, the EPA was in the process of reviewing the applications for the three new formulations of dicamba. It is an open question whether the USDA's 2015 decision to de-regulate GE (DT) soybean and cotton played a role in the 2016 EPA's decision to register the new versions of dicamba. If that was the case, it would need to be recognized that regulatory agencies are limited in their capacity to act autonomously (so as to advance the public interest) by the actions of other regulatory bodies who also have authority over that product or another product that is intended for use with it.

The regulation of new technological products presents a challenge for a third reason. Specifically, if states choose to afford patent holders very broad rights, regulatory agencies may not be able to attend to their duties to advance the public interest. For instance, patent holders could claim that they should not be obligated to provide their products (including patented GE organisms, herbicides, or pesticides) to university scientists, scientists working with civil society organizations, and even regulatory agency scientists for research purposes because that requirement is at odds with their patent rights. ${ }^{20}$

In response to that objection, a few things need to be said. The affording of such broad rights to developers of new technological products, in effect, gives them an epistemic monopoly over data, analyses, and evaluations of those artifacts. It undermines the ability of regulatory agencies to draw on a variety of sources for data, analyses, and assessments of new technological products' safety and efficacy. That impacts their capacity to rigorously assess those products, which is part of their duty to advance the public interest. The state-enabled domination of regulatory agencies by product developers could have public health and environmental consequences,

\footnotetext{
${ }^{20}$ For a different perspective on patents for pesticides, see Timmermann (2015). He has argued that pesticide effectiveness is a common human heritage and that heritage is undermined by chemical pesticides because such pesticides result in the target species developing pesticide resistance fairly quickly. Timmermann makes the case that developers of pesticides should not be afforded (standard) patent rights because, unlike other inventions, the knowledge provided by pesticide developers in the patent application becomes outdated prior to the expiration of the patent period. Invariably, the target species develop pesticide resistance, so not only is the knowledge (provided by the patent holder in the patent application) not of relevance, the product loses its usefulness. Moreover, pesticide manufacturers benefit if farmers overuse their products, although that puts at risk pesticide effectiveness (Timmermann, 2015, 14). (Farmers overuse pesticides and herbicides because target organisms have developed resistance to them (Lopez-Hernandez, 2020)). Timmmerman notes that in terms of profitability for agrochemical companies what matters is the good reputation of pesticides, "basically on how farmers think the pesticide will perform, not for the actual performance" $(2015,14)$.
} 
nationally and internationally. The actions of regulatory agencies can have very widespread significance.

It also needs to be pointed out that the patent objection is based on a fundamental misunderstanding about patent rights. Countries permit inventors to patent their novel inventions and thereby profit from them because the public interest will be served when, in return for the patent rights, they disclose how those inventions function and can be created and used (see, for instance, Shi (2008); Timmerman (2014); and especially patent expert Peter Drahos' works). Patents are not a social good that takes precedence over all other concerns.

Historically, the scope of patent rights was determined by individual state actors. Over the last few decades, some powerful members of the World Trade Organization have aggressively pushed for the international harmonization of patent regimes and those patent laws strongly favor patent-holding corporate actors (Drahos, 1995; 2003).

However, depending on their power on the global stage, countries do tailor their national patent regimes to varying degrees. Germany, for instance, does not give patent holders the power to bar or determine what kind of research may be conducted on their products (Biddle 2014, 20-21). In contrast, the USA affords patent holders much broader rights. Drawing on Waltz's (2009) research about Monsanto, Syngenta, and Pioneer Hi-Bred limiting the kind of research US scientists could conduct on their products, Biddle (2014) notes that the USA choses to give patent holders the right to decide to whom they provide their products for research and under what conditions. Legal scholar Rebecca Bratspies $(2017,607)$ has examined the broad scope of Monsanto's technology/stewardship agreement that are presumably based on its US patent rights:

[U]ntil recently, Monsanto's technology/stewardship agreements explicitly prohibited seed purchasers from conducting any research on the seeds. ${ }^{21}$ The agreements also prohibited a purchaser from supplying seeds to someone else for research purposes. ${ }^{22}$ As a result, there was no way for researchers to legally acquire seeds or conduct research without the explicit permission of the company involved. Researchers complained about needing to have "written permission from the companies for any science involving their seed, even if it was commercially available." ${ }^{23}$ To obtain this permission, researchers had to get the company to sign off on the research design. ${ }^{24}$ That gave the companies the power to choose who could study the crops and to dictate how the research would be conducted, giving them unfettered power to shape the information

\footnotetext{
21 In support of that claim, Bratspies $(2017,607)$ cited term 4(j) of Monsanto's 2015 Technology/Stewardship Agreement (Monsanto 2015) as well as Waltz $(2009,880)$.

22 Monsanto (2015, 4(j)) and Waltz (2009, 880) (cited in Bratspies $(2017,607)$ ).

23 Bratspies $(2017,607)$ cites Johnson (2013), who quotes Elson Shields, a corn-insect scientist at Cornell University.

24 Drawing on Pollack (2009) who cited an anonymous letter submitted to the EPA (Anonymous 2009), Bratspies $(2017,607)$ notes that "[I]n an unprecedented 2009 letter to EPA, twenty-six entomologists complained that the agricultural biotechnology companies were thwarting independent research on the effects of their GE crops."
} 
that would available. ${ }^{25}$ As a result, "[n]o truly independent research [could] be legally conducted on many critical questions,... unduly limit[ing]" the data that regulators had before them in making decisions about GE crops. ${ }^{26}$

Even more astonishing than the prior restrictions on academic research is the fact that these same research limitations extended to regulators. ${ }^{27}$ Indeed, it was only in 2010 that Monsanto and (USDA Agriculture Research Service) (ARS) negotiated a license that allowed the government-i.e., the regulators overseeing Monsanto- the freedom to conduct research without first asking Monsanto's express permission for each individual experiment (my italics). ${ }^{28}$

The larger point here appears to be that if a country permits patent holding actors to determine the conditions under which research may be conducted on their products by regulatory agency scientists and third-party scientists and the results publicly disseminated, it, in effect, creates condition for the domination of regulatory agencies. It allows the patent holder to have an epistemic monopoly, which impairs efforts of regulatory agencies to conduct rigorous evaluations of new technological products so to determine their safety and efficacy. A state that affords overly broad patent rights undermines its own regulatory agencies' efforts to advance the public interest.

Developers of technological products should welcome scrutiny of their products by third parties. It could help them identify serious problems early on and devise solutions for them. It could also help them decide whether they should try to bring those products to the market at all if they are fundamentally flawed or radically at odds with the terms under which a certain kind of technology may be used in a particular country.

\section{Conclusion}

This paper argued that regulatory agencies must advance the public interest as they regulate new technological products. To make that case, it drew on the 9th Circuit Court's ruling against the EPA with regards to the commercial use of three newly developed lower volatility formulations of dicamba. The ruling has broad relevance for regulatory agencies in democracies. To foster the public interest, regulatory agencies must assess new technological products in a substantively and procedurally disinterested manner. Among other things, it means they must evaluate them by drawing on data, analyses, and evaluations from a variety of credible epistemic sources, rather than rely solely or primarily on sources that have a vested interest in them. Moreover, they should be particularly attentive to the analyses and assessments of the new technological products developed by those who would be most at risk from them or by those who represent such parties.

\footnotetext{
${ }^{25}$ Bratspies references the following quote from Waltz $(2009,880)$ : "Seed companies can refuse a research request for any reason, and they get fairly inventive."

${ }^{26}$ Bratspies $(2017,607)$ cites the anonymous comment on FIFRA Scientific Advisory Panel (see footnote 24) in support of this claim.

${ }^{27}$ Citing Waltz (2009), Bratspies $(2017,607)$ notes that the "the 2009 anonymous public comment was, at least in part, comprised of ARS scientists".

${ }^{28}$ See footnote 27.
} 
Relatedly, regulatory agencies should issue guidances instructing product developers to provide their products for study to third parties that are not funded or affiliated with them. For instances, university scientists and civil society organization scientists should be provided with the newly developed technological products so that they can analyze and evaluate them and provide their reports to regulatory agencies before they are commercialized. Regulatory agencies should have those studies and reports in hand as they consider whether the new technologies should be authorized for commercial use. Moreover, regulatory agency scientists (that have no ties or interaction with the product developer) should be able to conduct research on the products that they are evaluating, without needing the patent holder's permission. Last, but not least, advancing the public interest requires that democratic states create conditions-nationally and internationally-such that regulatory agencies do not have to solely (or primarily) depend on the data, analyses, and evaluations provided to them by product developers.

Acknowledgements The author wishes to thank the anonymous reviewers of this article for their thoughtful and helpful comments. The APC was covered by the Ebbs fund.

Open Access This article is licensed under a Creative Commons Attribution 4.0 International License, which permits use, sharing, adaptation, distribution and reproduction in any medium or format, as long as you give appropriate credit to the original author(s) and the source, provide a link to the Creative Commons licence, and indicate if changes were made. The images or other third party material in this article are included in the article's Creative Commons licence, unless indicated otherwise in a credit line to the material. If material is not included in the article's Creative Commons licence and your intended use is not permitted by statutory regulation or exceeds the permitted use, you will need to obtain permission directly from the copyright holder. To view a copy of this licence, visit http://creativecommons.org/licen ses/by/4.0/.

\section{References}

Anonymous. (2009). Comment on FIFRA Scientific Advisory Panel; Notice of public meeting. February 10. Available at:https://www.regulations.gov/document/EPA-HQ-OPP-2008-0836-0044. Accessed 22 Aug 2021

Barkow, R. E. (2010). Insulating agencies: Avoiding capture through institutional design. Tex. l. Rev., 89, 15.

Barry, B. (1964). The public interest. Proceedings of the Aristotelian Society 38 (supplementary volume): $1-18$.

Benbrook, C. M. (2016). Trends in glyphosate herbicide use in the United States and globally. Environmental Sciences Europe, 28(1), 3.

Bird, T., Steffen, JE., Tran, TH., \& Egilman, D. S. (2021). A review of the talc industry's influence on federal regulation and scientific standards for asbestos in talc. New Solutions: a Journal of Environmental and Occupational Health Policy, 31(2), 152-169. https://journals.sagepub.com/doi/pdf/10. 1177/1048291121996645. Accessed Aug 242021

Bohme, S. R., Zorabedian, J., \& Egilman, D. S. (2005). Maximizing profit and endangering health: Corporate strategies to avoid litigation and regulation. International Journal of Occupational and Environmental Health, 11(4), 338-348.

Boot, E. R. (2020). The feasibility of a public interest defense for whistleblowing. Law and Philosophy, 39(1), 1-34.

Bratspies, R. (2017). Owning all the seeds: Consolidation and control in Agbiotech. Envtl. l., 47, 583-607.

Brink, D. O. (2010). Mill's Ambivalence about Rights. BUL Rev., 90, 1669.

Croley, SP. (2007). Regulation and public interests: the possibility of good regulatory government. Princeton UP. 
Drahos, P. (1995). Global property rights in information: the story of TRIPS at the GATT. Prometheus, 13(1), 6-19. Available at: https://www.anu.edu.au/fellows/pdrahos/articles/pdfs/1995globalpropr ightsinfo_drahos.pdf. Accessed 22 Aug 2021

Drahos, P. (2003). When the weak bargain with the strong: negotiations in the World Trade Organization. International Negotiation, 8(1), 79-109. Available at: https://www.researchgate.net/profile/PeterDrahos/publication/228195255_When_the_Weak_Bargain_with_the_Strong_Negotiations_in_the_ World_Trade_Organization/links/5c0b6c69a6fdcc494fe202de/When-the-Weak-Bargain-with-theStrong-Negotiations-in-the-World-Trade-Organization.pdf. Accessed 22 Aug 2021

Ferdman, A., \& Kohn, M. (2018). The theory and politics of solidarity and public goods. Critical Review of International Social and Political Philosophy, 21(5), 545-553.

Fernández Pinto, M., \& Hicks, D. J. (2019). Legitimizing values in regulatory science. Environmental Health Perspectives, 127(3), 035001.

Floridi, L. (2021). Trump, Parler, and regulating the infosphere as our commons. Philos. Technol., 34, 1-5. https://doi.org/10.1007/s13347-021-00446-7

Friedman, M. (2003). Autonomy, gender, politics. Oxford UP.

Gaines, T., Slavov, G., Hughes, D., et al. (2020). Investigating the origins and evolution of a glyphosateresistant weed invasion in South America. Authorea Preprints.

Guy, M. E., \& McCandless, S. A. (2012). Social equity: Its legacy, its promise. Public Administration Review, 72(s1), S5-S13.

Harrison, J. L. (2011). Pesticide drift and the pursuit of environmental justice. MIT Press.

Hubbard, K., \& Hassanein, N. (2013). Confronting coexistence in the United States: Organic agriculture, genetic engineering, and the case of Roundup Ready® alfalfa. Agriculture and Human Values, $30(3), 325-335$.

International Panel of Experts on Sustainable Food Systems (IPES). (2017). Too big to feed: exploring the impacts of mega-mergers, concentration, concentration of power in the agri-food sector. http:// www.ipes-food.org/_img/upload/files/Concentration_FullReport.pdf. Accessed 24 Aug 2021

International Service for the Acquisition of Agri-biotech Applications (ISAAA). (2019). ISAAA Brief 55-2019: Executive summary: biotech crops drive socio-economic development and sustainable environment in the new frontier. Available at: https://www.isaaa.org/resources/publications/briefs/ 55/executivesummary/default.asp. Accessed 24 Aug 2021

Jasanoff, S. (2011). Constitutional moments in governing science and technology. Science and Engineering Ethics, 17(4), 621-638.

Johnson, N. (2013). Genetically modified seed research: what's locked and what isn't. Grist (Aug. 5). Available at: https://perma.cc/HZ7L-JYVX. Accessed 24 Aug 2021

Kant, I. (1785) [1983]. Grounding for the metaphysics of morals, in I. Kant, Ethical Philosophy, James W. Ellington (trans.). Hackett.

Krimsky, S. (2017). The unsteady state and inertia of chemical regulation under the U.S. Toxic Substances Control Act. PLoS Biol, 15(12), e2002404.

Krimsky, S. (2021). Can glyphosate-based herbicides contribute to sustainable agriculture? Sustainability, 13(4), 2337.

Krimsky, S., \& Gillam, C. (2018). Roundup litigation discovery documents: Implications for public health and journal ethics. Journal of Public Health Policy, 39(3), 318-326.

Landis, JM. (1960). Report on regulatory agencies to the President-elect 71.

Latin, H. (1991). Regulatory failure, administrative incentives, and the New Clean Air Act. Environmental Law, 21, 1647.

Lerner, S. (2021). The Department of Yes: How Pesticide Companies Corrupted the EPA and Poisoned America. The Intercept. https://theintercept.com/2021/06/30/epa-pesticides-exposureopp/. Accessed 24 Aug 2021

Lexchin, J. (2012). Those who have the gold make the evidence: How the pharmaceutical industry biases the outcomes of clinical trials of medications. Science and Engineering Ethics, 18(2), 247-261.

Liang, J., Park, S., \& Zhao, T. (2020). Representative bureaucracy, distributional equity, and environmental justice. Public Administration Review, 80(3), 402-414.

Loddo, D., Imperatore, G., Milani, A., et. al. (2020). First report of glyphosate-resistant biotype of Eleusine Indica (L.) Gaertn in Europe. Agronomy, 1692.

Lopez-Hernandez, E. (2020). Gmo Corn, Mexico, and Coloniality. Vanderbilt Journal of Entertainment \& Technology Law, 22(4), 725.

Lyons, D. (1994). Rights, welfare, and Mill's moral theory. Oxford UP. 
Magill, ME. (2011). Courts and regulatory capture. In Preventing capture: special interest influence in regulation, and how to limit it. Daniel Carpenter, Steve Croley, and David Moss, eds. 397-419.

McGarity, T. (2003). Our science is sound science and their science is junk science. University of Kansas Law Rev, 52, 897-937.

Meghani, Z. (2014). Risk assessment of genetically modified food and neoliberalism: An argument for democratizing the regulatory review protocol of the Food and Drug Administration. Journal of Agricultural and Environmental Ethics, 27(6), 967-989.

Meghani, Z. (2017). Genetically engineered animals, drugs, and neoliberalism: The need for a new biotechnology regulatory policy framework. Journal of Agricultural and Environmental Ethics, 30(6), $715-743$.

Meghani, Z. (2019). Autonomy of nations and Indigenous peoples and the environmental release of genetically engineered animals with gene drives. Global Policy, 10(4), 554-568.

Meghani, Z. (2020). The hard sell of genetically engineered (GE) mosquitoes with gene drives as the solution to malaria: ethical, political, epistemic, and epidemiological issues in global health governance. In Crasnow, S., \& Intemann, K. (Eds.), The Routledge handbook of feminist philosophy of science (pp. 435-457). Routledge.

Monsanto. (2015). Monsanto technology/stewardship agreement (Limited Use License). Accessed on 24 August 2021 at: https://gmoban.files.wordpress.com/2016/06/monsanto-technology-stewardshipagreement-2015-2-pages.pdf

National Family Farm Coalition v. Environmental Protection Agency, No. 19-70115 (9th Cir. 2020). Accessed on 24 August 2021 at: https://law.justia.com/cases/federal/appellate-courts/ca9/19-70115/ 19-70115-2020-06-03.html

Nielsen, K. (1985). Equality and liberty: A defense of radical egalitarianism. Rowman \& Littlefield.

Noah, L. (1997). The FDA's new policy on guidelines: Having your cake and eating it too. Cath. UL Rev., $47,113$.

O'Flynn, I. (2010). Deliberating about the public interest. Res Publica, 16(3), 299-315.

Oreskes, N. \& Conway, EM. (2010). Merchants of doubt: how a handful of scientists obscured the truth on issues from tobacco smoke to global warming. Bloombury.

Pollack, A. (2009). Crop scientists say biotechnology seed companies are thwarting research. N.Y. Times, Feb. 19, p.B3.

Proctor, R. (2012). Golden holocaust: Origins of the cigarette catastrophe and the case for abolition. University of California Press.

Ravet, K., Sparks, C., Dixon, A., et al. (2020). Genomic-based epidemiology reveals gene flow and independent origins of glyphosate resistance in Bassia scoparia populations across North America. Authorea Preprints.

Schroeder, B. (2020). Ninth Circuit vacates EPA registration of three dicamba herbicides. IndyBar, June 18th. https://www.indybar.org/?pg=EnvironmentalLawNews\&blAction=showEntry\&blogEntry= 55409. Accessed 24 Aug 2021

Schwartzman, LH. (2006). Challenging liberalism: feminism as political critique. Penn State Press.

Shapiro, S. A. (2012). The complexity of regulatory capture: Diagnosis, causality, and remediation. Roger Williams UL Rev., 17, 221.

Shi, W. (2008). The justification for IPR protection. Intellectual property in the global trading system: EU-China perspective. Springer. 23-66.

Skinner, Q. (2002). A third concept of liberty. Proceedings of the British Academy, 117, 237-268.

Smuha, NA. (2020). Beyond a human rights-based approach to AI governance: promise, pitfalls, plea. Philos. Technol, pp.1-14.

Stewart, RB. (1975). The reformation of American administrative law. Harvard Law Review, 88, $1667-1813$.

Svara, J. H., \& Brunet, J. R. (2005). Social equity is a pillar of public administration. Journal of Public Affairs Education, 11(3), 253-258.

Taylor, L. (2021). Public actors without public values: legitimacy, domination and the regulation of the technology sector. Philosophy \& Technology, 1-26. https://link.springer.com/article/10.1007/ s13347-020-00441-4. Accessed 24 Aug 2021

Tran, T. H., Steffen, J. E., Clancy, K. M., Bird, T., \& Egilman, D. S. (2019). Talc, asbestos, and epidemiology: corporate influence and scientific incognizance. Epidemiology (Cambridge, Mass.), 30(6), 783. 
Trasande, L., Vandenberg, L. N., Bourguignon, J., et al. (2016). Peer-reviewed and unbiased research, rather than 'sound science', should be used to evaluate endocrine-disrupting chemicals. J Epidemiol Community Health., 70(11), 1051-1056. https://doi.org/10.1136/jech-2016-207841

US Department of Agriculture, Economic Research Service (ERS). (2020). Adoption of genetically engineered crops in the U.S.: recent trends in GE adoption. Accessed on 24 Aug 2021 at: https://www. ers.usda.gov/data-products/adoption-of-genetically-engineered-crops-in-the-us/recent-trends-in-geadoption.aspx

US Environmental Protection Agency (EPA). (2020). EPA announces 2020 dicamba registration decision. Accessed on 24 Aug 2021 at: https://www.epa.gov/newsreleases/epa-announces-2020-dicam ba-registration-decision

US Environmental Protection Agency (EPA). (undated). EPA guidance document. Accessed on 24 Aug 2021 at: https://www.epa.gov/guidance

US FDA. (2016). Guidance. Available at: https://www.fda.gov/ForIndustry/FDABasicsforIndustry/ ucm234622.htm. Accessed 22 Aug 2021

Waltz, E. (2009). Under wraps. Nature Biotechnology, 27,10, 880-882. Accessed on 24 Aug 2021 at: https://hstrialewaltz. homestead.com/Biotech_crop_research_restrictions_Oct_2009.pdf

Waltz, E. (2010). Monsanto relaxes restrictions on sharing seeds for research. Nature Biotechnology 28, 996. Accessed on 24 Aug 2021 at: https://perma.cc/B6CG-SYLP

Weimer, D. L. (2006). The puzzle of private rulemaking: Expertise, flexibility, and blame avoidance in US regulation. Public Administration Review, 66(4), 569-582.

Welch, D., Shapiro, S., Christenson, S., et al. (2006). Letter to US EPA Administrator Stephen Johnson from local presidents of EPA unions representing scientists, risk managers, and related staff. Accessed on 24 August 2021 at: https://www.panna.org/sites/default/files/epa\%201tr\%2024may06. pdf

Young, IM. (1990). Justice and the politics of difference. Princeton UP

Young, IM. (2002). Inclusion and democracy. Oxford UP

Publisher's Note Springer Nature remains neutral with regard to jurisdictional claims in published maps and institutional affiliations. 